\title{
Promoting Access to Intellectual Property: Patent Pools, Copyright Collectives and Clearinghouses ${ }^{*}$
}

\author{
Reiko Aoki \\ Institute of Economic Research, \\ Hitotsubashi University \\ and Department of Economics, \\ University of Auckland \\ aokirei@ier.hit-u.ac.jp
}

\author{
Aaron Schiff \\ Institute of Economic Research, \\ Hitotsubashi University \\ aschiff@ier.hit-u.ac.jp
}

REVISED, 28 September 2007

\begin{abstract}
This paper reviews and compares patent pools, intellectual property clearinghouses and copyright collectives as systems for promoting efficient access to licensable intellectual property in a 'market for technology' (Arora et al, 2001). These systems promote downstream use of innovations by economizing on search and transaction costs in licensing, as well as potentially mitigating the conditions that lead to the 'tragedy of the anti-commons' and other coordination problems in multilateral licensing. We compare and classify different systems in terms of their features, review some existing systems, and discuss their economic characteristics.
\end{abstract}

Keywords: Intellectual property, licensing, markets for technology, collective rights management, patent pools, clearinghouses.

\footnotetext{
* We thank two anonymous referees, Geertrui Van Overwalle and Esther van Zimmeren for helpful comments and suggestions, and the Japan Society for the Promotion of Science for financial support.
} 


\section{Introduction}

Intellectual property (IP) rights are granted to give incentives for undertaking costly research and development. Legal institutions such as patents and copyrights reward innovation by temporarily restricting competition in the production of the resulting goods and services. The number of copyrighted works that exist is difficult to measure because registration is not typically required, but Figure 1 shows the number of patents granted by the U.S. Patents and Trademarks Office (USPTO) and the number of patent applications that were submitted to all three of the USPTO, the European Patent Office (EPO) and the Japan Patent Office (JPO) ('triadic' patent applications) per year. Both data series exhibit an upwards trend over time with average annual growth rates over the periods shown of $3.4 \%$ and $4.9 \%$ respectively.

Figure 1 Patents granted by the USPTO, and the number of patent applications that were submitted to all three of the USPTO, EPO and JPO.

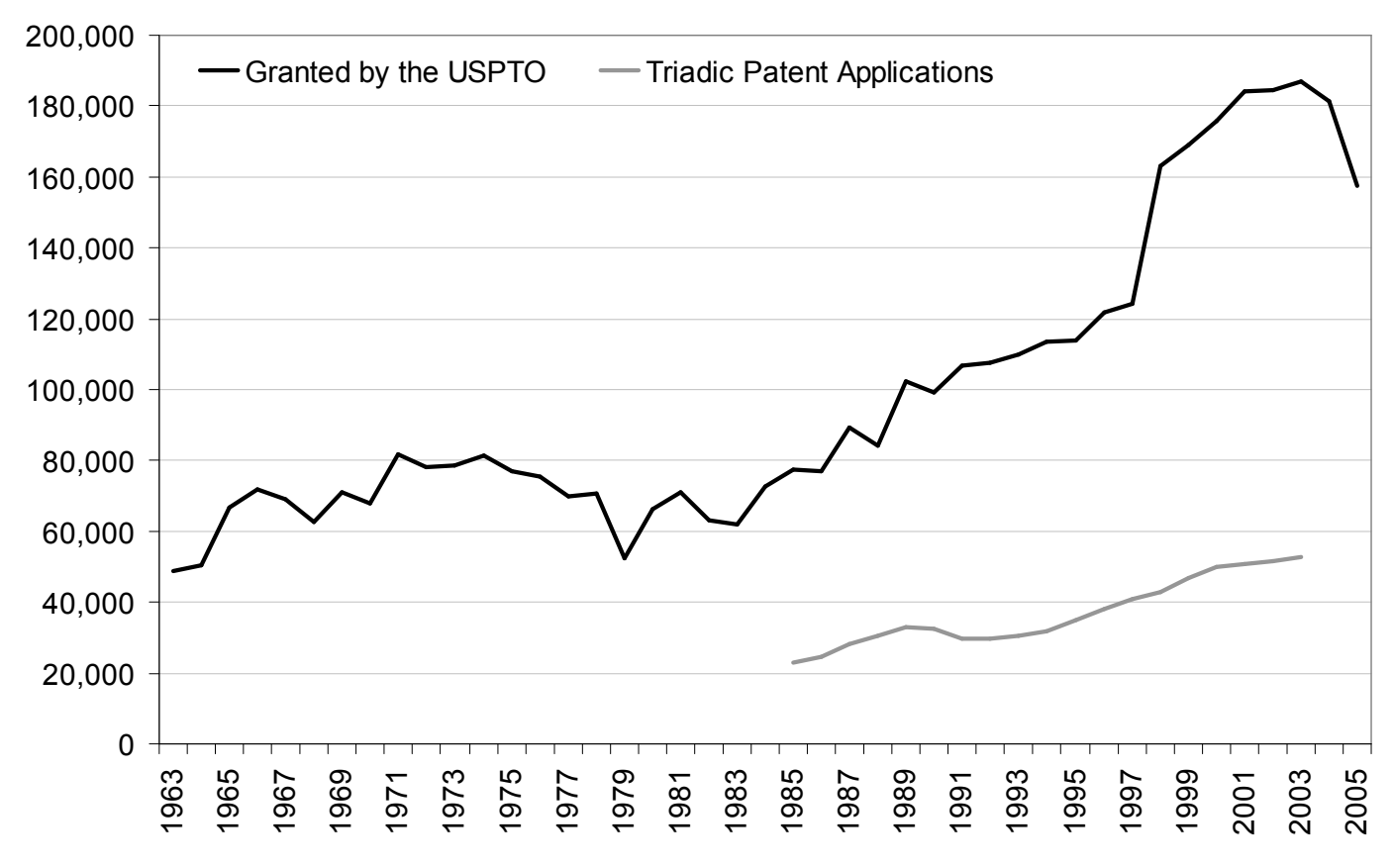

Sources: USPTO (2005), OECD (2006).

More recently, there has been significant growth in the information technology and communications (ICT) and biotechnology, medical and pharmaceutical (BMP) sectors in many countries. Figure 2 shows the number of patents issued by the USPTO and applications made to the EPO per year for technologies related to these fields. The number of ICT patents has grown relatively steadily, while BMP patents experienced rapid growth up to 1997, followed by a period of stagnation and then decline. A similar 
trend is observed in Table 1, which shows the number of patents issued by the USPTO to five top biotechnology firms.

Figure $2 \mathrm{BMP}$ and ICT patents issued by the USPTO and applications made to the EPO.


Sources: USPTO (2005), OECD (2006). The USPTO data were classified into BMP and ICT categories by the authors. The classification system used is available from the authors on request.

Table 1 Patents issued to five leading biotech firms by the USPTO, by year of filing.

\begin{tabular}{|lrrrr|}
\hline & $\mathbf{8 6 - 9 0}$ & $\mathbf{9 1 - 9 5}$ & $\mathbf{9 6 - 0 0}$ & $\mathbf{0 1 - 0 5}$ \\
Amgen & 25 & 270 & 374 & 203 \\
Genentech & 161 & 733 & 669 & 266 \\
Serono & 30 & 7 & 3 & 56 \\
Biogen & 48 & 115 & 87 & 58 \\
Genzyme & 13 & 119 & 255 & 108 \\
TOTAL & 277 & 1,244 & 1,388 & 691 \\
\hline
\end{tabular}

Sources: The firms are identified from the list of top ten biotech firms at www.researchandmarkets.com, ${ }^{1}$ and patents were found via Google's patent search, www.google.com/patents/.

In the context of patents, a proliferation of IP rights may result in a 'patent thicket' (Shapiro, 2001) that can increase costs for downstream activities such as cumulative innovation and the development of new products that combine multiple existing innovations. For example, the above data indicate that that in the United States there are currently more than 300,000 active BMP patents and 500,000 active ICT patents. The more existing IP rights that cover a given downstream activity, the higher will be the transaction costs associated with licensing. In addition, if the upstream IP rights are complementary, potential coordination failures among IP owners can lead to excessively high licensing fees. Similar issues exist for downstream users of copyrighted works such as radio and television stations that combine multiple copyrighted works to make broadcast programs.

1 "The Top 10 Biotechnology Companies", August 2005. This list identifies UCB-Celltech as the fifth firm. However, UCB-Celltech undertakes many other activities in addition to biotechnology, thus it was excluded from the table. 
Another clear trend in IP has been the growth of licensing. Athreye and Cantwell (2007) report that worldwide royalty and license revenues reached almost 80 billion US dollars in 2000, up from around 10 billion US dollars in 1983. Significant amounts of licensing are also reported by Razgaitis (2005) based on a 2004 survey of 472 firms engaged in licensing in the U.S. and Canada. In total, 14.4 billion US dollars of in-licensing payments and 9.0 billion US dollars of out-licensing revenues were reported by the firms surveyed for 2004. Figure 3 shows the uses of patented innovations reported by the holders of more than 9,000 European patents (Giuri \& Mariani et al 2007), for different types of organization. On average, $10.1 \%$ of all patents were either licensed by their owner or both used and licensed by the owner. High rates of licensing occur among public and private research institutions, universities and other government institutions, and small firms. All this data points to 'markets for technology' (Arora et al, 2001), where innovations are bought and sold, becoming increasingly important in facilitating downstream uses of IP.

Figure 3 Use of patents reported in the European PatVal-EU survey (Giuri \& Mariani et al 2007).



The proliferation of IP rights and growth of licensing is good news in the sense that these are broad indicators of growth in innovative activities, which are a key driver of economic growth. In addition, licensing IP is a substitute for an innovator doing its own production, and some firms may be more efficient at production than others. Thus outsourcing of production through licensing may be efficient. On the other hand, a situation such as a patent thicket is likely to impose additional costs and inefficiency on 
downstream product development and cumulative innovation. For example, development of a new genetic diagnostic test typically requires licenses to a number of patents on gene sequences and related technologies (Scherer, 2002). The greater the number of licenses required, the greater the cost of developing the new test. This paper is concerned with ways that these costs can be reduced so that markets for technology can function more efficiently.

There is also some evidence that markets for technology do not function as efficiently as their participants desire. In an earlier survey, Razgaitis (2004) reported that among organizations involved in significant licensing activities, $43 \%$ of licensing negotiations terminated unsuccessfully. Failure was reported to occur because there were either too many parties to the negotiation or because a useful bundle of IP could not be assembled in $9 \%$ of failed out-licensing negotiations and $12 \%$ of failed in-licensing negotiations. Among the patents in the PatVal-EU survey, 11\% were licensed, and for a further $7 \%$ the owner was willing to license but had been unable to do so (Gambardella et al, 2007).

In this paper we examine ways to facilitate access to IP in order to reduce the costs and inefficiencies identified above. We focus on economic systems that operate through market mechanisms, rather than regulatory or legal approaches such as research exemptions and compulsory licensing. We will consider two basic types of system: patent pools and IP clearinghouses. ${ }^{2}$ We use the term IP access system as a generic label that encompasses both patent pools and clearinghouses. These operate as intermediaries in markets for technology and economize on search and transaction costs by aggregating information about technologies, as well as promoting economies of scale in licensing and negotiation. In some cases they also help to generate more efficient prices for licensing complementary IP. Some specific examples include patent pools like the MPEG-2 and DVD pools, and clearinghouse businesses like Yet2.com which provide a platform for advertising licensable technologies. Our definition of clearinghouses also encompasses collective rights management organizations such as copyright collectives. Further examples are given in section 3. Our specific objectives are to classify IP access systems, compare their organizational and economic features, review existing systems, and identify directions for future economic research.

\footnotetext{
${ }^{2}$ Another alternative is the idea of 'open source' innovation whereby each innovator licenses their innovation to others at no cost, on the condition that licensees use the same kind of license. The open source model has found some success in software development. However, much of this success has been due to the efforts of individual programmers who have a range of personal motivations for participating. It is more difficult to see how the same model could be widely applied in the field of biotechnology, for example, where development costs are large, and many of the innovators are profit-driven firms. See Hope (2004) for a discussion of open source in the context of biotechnology.
} 
Some similar issues are discussed by Shapiro (2001), who considers the strategies that firms may employ to reduce the effects of a patent thicket on their ability to innovate. Shapiro considers the strategies of cross licensing, patent pools, and cooperative standard setting. Our paper is complementary to Shapiro's in that our analysis is at the level of the market for technology, rather than an individual firm. We also consider IP clearinghouses that operate independently from the innovating firms, and focus on systems that could be centralized and operated by a third-party, so we exclude cross licensing. There is also an extensive economic literature on the incentives of innovators to license intellectual property, and the optimal licensing contracts to use if they choose to do so. ${ }^{3}$ In this paper we take the decision about whether or not to license as given, and focus on market mechanisms that bring licensors and licensees together.

The organization of the rest of this paper is as follows. The next section discusses the effects of a proliferation of IP rights on economic efficiency in markets for technology. Section 3 describes the general characteristics of an IP access system, their classification, and specific features of the systems discussed in this paper. Section 4 then compares the economic features of different systems and the effects on markets for technology. Section 5 concludes and suggests directions for future research.

\section{Economic Effects of IP Proliferation}

Arora et al (2001) discuss the idea of a 'market for technology', where innovations available for licensing are supplied by innovators and where licensing transactions occur. We use this framework to analyze the effects of IP proliferation and the impact that IP access systems have on the downstream use of licensed innovations.

Figure 4 summarizes the basic conceptual framework, for the case of downstream product development. Upstream, innovations available for licensing are supplied into the market for technology. Demand for licenses comes from firms that produce final goods sold to consumers. The prices of licenses are determined in this market, which affect both the costs of producers and the revenues of innovators. Producers then supply products to meet demand from final consumers. The prices determined in the product markets affect the revenues of producers and the expenditure (and hence welfare) of the final consumers. Although for illustration we show innovators and producers as separate, in some cases they may be vertically integrated. Figure 4 depicts the case where licensed innovations are used to produce final goods and services. Alternatively, licenses may be used to produce cumulative innovations. If the cumulative innovation is

\footnotetext{
${ }^{3}$ For example, Gallini and Wright (1990), Kamien and Tauman (1986), Katz and Shapiro (1985), and Arora and Fosfuri (2003).
} 
sold to final consumers, then the situation is essentially the same as shown in the figure. If the cumulative innovation is itself licensed for downstream use, then it will be sold in the market for technology.

Figure 4 Relationships between markets for technology and downstream product markets.

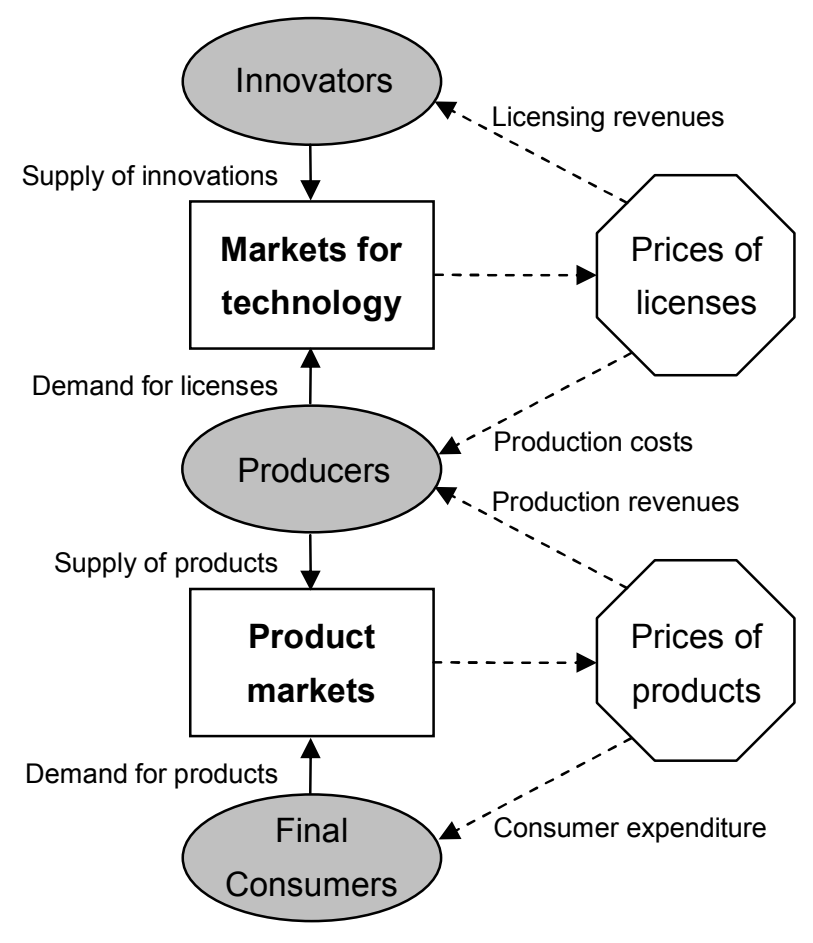

In general, the more IP rights that exist within a given field, the greater the potential supply of licensable innovations and the greater the range of downstream products that can be produced. This is beneficial from an economic point of view as consumers get value from new products. However, as the number of IP rights increases, it is possible that the licensing process can become 'congested', resulting in increased costs and inefficiencies. We can distinguish three costs that congestion may impose on the development of cumulative innovations or downstream products that combine multiple innovations.

First, downstream users of IP will face increasing search costs as it becomes more timeconsuming and difficult to identify relevant existing IP rights. Second, if relevant IP rights exist, licenses will need to be negotiated. Since negotiating licenses can be complex and expensive, the more licenses that need to be negotiated, the greater the transaction costs innovators and licensors will face. Third, if a new innovation or product needs access to multiple complementary IP rights, the tragedy of the anti-commons (Heller \& Eisenberg, 1998, Buchanan \& Yoon, 2000) may arise, whereby coordination failures 
among upstream IP owners result in the total fee charged to downstream users being excessively high.

Search and transaction costs and the tragedy of the anti-commons affect economic outcomes in the market for technology. The costs of licensing and the license fees that arise in the market for technology determine, together with downstream demand, the downstream uses that are economically viable, and the prices charged to final users. This determines economic welfare and the distribution of welfare among consumers, producers and innovators. In addition, innovators will base their decisions about whether to invest in research and development and whether to license their innovations at least partially on expectations of licensing revenues. Thus the final economic outcomes feed back into the incentives to innovate. Figure 5 summarizes these effects.

Figure 5 Linkages between conditions in the market for technology and economic outcomes.

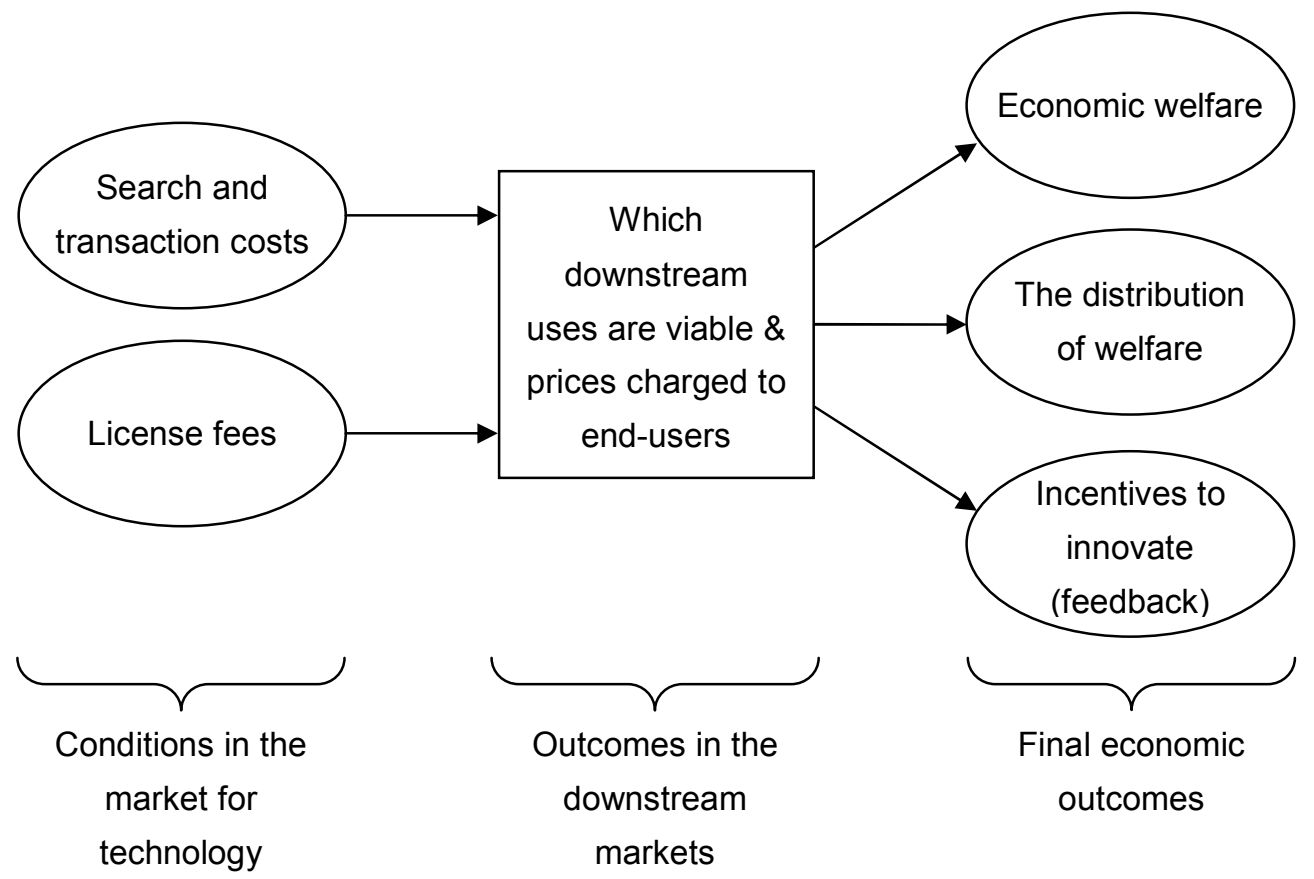

Of the three adverse effects of IP proliferation that we have identified, increasing search and transaction costs are easy to understand. Both increase the cost of downstream uses of innovations. If these costs could be avoided or reduced, then the downstream activities would be cheaper, and the resources saved could be put to alternative uses, resulting in productive efficiency gains. In addition, if the search and/or transaction costs for a particular downstream use are too large, the project may become unviable and it may not be undertaken at all, resulting in further lost economic benefits. 
The third effect, the tragedy of the anti-commons, needs some further explanation. Suppose that licenses to two existing complementary technologies, A and B, are required to produce a third technology, $C$. The producers of $C$ must pay royalties $r_{A}$ and $r_{B}$ to the owners of the patents on A and B for each unit of $C$ that is sold. Assume there are no other costs of producing $C$ aside from the royalties. Assume also that $C$ is competitively supplied, so that its price equals its marginal cost, which is $r_{A}+r_{B}$. In this situation, an increase in either $r_{A}$ or $r_{B}$ will increase the per-unit cost (and hence the price) of $C$ and will result in fewer units of $C$ being sold.

The tragedy of the anti-commons arises in this situation because the owner of the patent on $\mathrm{A}$, for example, will not account for the fact that an increase in $r_{A}$ reduces the royalty revenues received by the owner of patent on $B$, since fewer units of $C$ will be sold when $r_{A}$ increases. In other words, the choice of $r_{A}$ by the owner of the patent on A imposes an externality on the owner of the patent on $B$, and vice versa. This means that the total royalty per unit of $C, r_{A}+r_{B}$, will end up being too high from the point of view of maximizing the joint royalty revenues. On the other hand, if the royalties were set by the patent holders in cooperation to maximize their joint revenues then the externalities would be internalized. The total royalty per unit of $C$ would be lower but total royalty revenues higher than when the royalties are set independently. Since this would also mean a lower price of $C$, it makes the consumers of $C$ better off as well. In a more general example, it is also possible to show that the total royalty that results when IP owners act independently increases with the number of IP owners. In other words, the more property rights that bear upon a downstream use, the worse is the tragedy of the anti-commons.

From a static efficiency point of view, production of the new innovation $C$ will be inefficiently low when royalties are set independently. The tragedy of the anticommons may also generate dynamic efficiency losses. If the creation of $C$ requires fixed costs (such as further research and development), this will only be undertaken if the profits from selling $C$ are expected to exceed these costs. If the total royalty payments to $A$ and $\mathrm{B}$ are too high, $\mathrm{C}$ may not be produced at all.

Note that cooperative determination of the royalties is only beneficial if $A$ and $B$ are complementary. Suppose instead that A and B are perfect substitutes. In this case, the producers of $C$ will simply choose whichever has the lowest royalty and competition between $\mathrm{A}$ and $\mathrm{B}$ will force royalties down to the lowest level that just covers their research and development costs. If, however, the owners of the rights to A and B jointly set their royalties, they could collude to undermine this competitive process and increase their profits. This would be beneficial for them, but it would hurt consumers of $\mathrm{C}$ as the price of $\mathrm{C}$ would rise. It can be shown that this outweighs the gains of the 
patent owners, and so economic efficiency reduces. Therefore, cooperation in setting royalties is only desirable when the technologies are complements, not substitutes. More general cases where patents are neither perfect substitutes nor perfect complements are analyzed by Lerner and Tirole (2004), who give specific conditions under which patent pools are efficiency-enhancing, in terms of the degree of complementarity of the patents.

To summarize, a proliferation of IP rights increases search and transaction costs for downstream uses. In addition, for uses that rely on licenses to complementary technologies, the tragedy of the anti-commons may result in inefficiently high license fees. ${ }^{4}$ Any of these effects potentially result in both static and dynamic efficiency losses.

\section{Description and Classification of IP Access Systems}

In this section we describe some of the IP access systems that exist in response to the problems outlined in the previous section. As discussed in the introduction, we focus on systems that can be centralized for operation by a third-party: patent pools and IP clearinghouses. We consider four types of IP clearinghouse, of which one type encompasses collective rights management organizations such as copyright collectives.

The basic role played by an IP access system in the process of innovation is illustrated in Figure 6, which shows where IP access systems fit in the framework of Figure 4 . In the absence of a system, IP is licensed in a decentralized manner, with innovators and users of IP finding each other and making licensing arrangements independently. When an IP access system exists, it provides a "platform" that facilitates interactions between innovators and IP users.

Different IP access systems can be distinguished along a number of dimensions. The important dimensions are shown in Figure 7. Systems may be collectives that satisfy a joint objective of the member IP owners, or third-parties with their own objectives. This may be profit maximization, or some other objective such as efficient cost recovery for non-profit systems. The systems may also be relatively open or closed in terms of their admission of different IP rights, and may just provide information about IP, or may provide both information and licenses. We will discuss the differences between systems in terms of these dimensions.

\footnotetext{
${ }^{4}$ Some authors use the term 'anticommons' to refer to what we have called the tragedy of the anticommons as well as increased search and transaction costs. In this paper we will always refer to the tragedy of the anticommons and search and transaction costs separately. In addition, under our definition, the tragedy of the anticommons is exactly the mirror image of the well-known tragedy of the commons.
} 
Figure 6 Basic function of an IP access system in the market for technology.

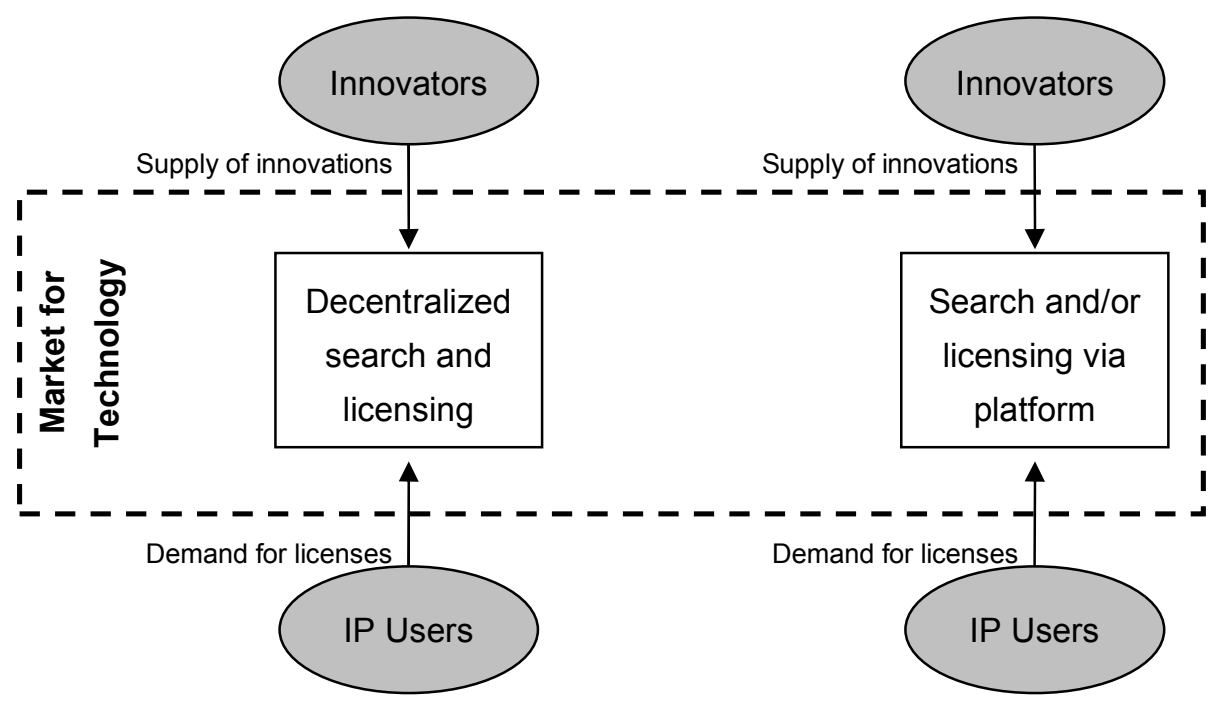

Figure 7 Key dimensions that distinguish IP access systems.

\begin{tabular}{|c|c|c|c|}
\hline Ownership & Objective & Entry of IP & Function \\
\hline Third-party & $\begin{array}{c}\text { Profit/Revenue } \\
\text { Maximization }\end{array}$ & Open & Information Only \\
\hline Collective & $\begin{array}{c}\text { Cost Recovery / } \\
\text { Other }\end{array}$ & Restricted & $\begin{array}{c}\text { Information \& } \\
\text { Licensing }\end{array}$ \\
\hline
\end{tabular}

\subsection{Patent Pools}

A patent pool is an arrangement between two or more patent holders in which the relevant patents are licensed jointly as a package. The licensees may be the patent holders themselves, other users of the technology, or both. Patent pools are often based around a specific technology or standard. Obtaining a single license from the pool means that the licensee has access to all of the IP covered by the patents in the pool and standardized licenses are typically offered to anyone who wants one. Recent examples include the MPEG-2 (video encoding) and 3G (mobile telecommunications) pools. ${ }^{5}$ In information technology industries, formation of a pool around a common technological standard is relatively straightforward, and it is possible to identify which patents are essential to the standard. In biotechnology and pharmaceuticals, pool formation may be

\footnotetext{
${ }^{5}$ See Aoki (2005) and Aoki \& Nagaoka (2005) for summaries of these pools.
} 
more difficult as technical standards are harder to define precisely. Some working examples include the 'Golden rice' and SARS pools. ${ }^{6}$

It is common for patent pools to be either administered by a management organization on behalf of the members, or by one or more of the members of the pool on behalf of all members. For example, the MPEG 2 pool (currently 23 members) is administered by the independent MPEG-LA organization, while the DVD3C and DVD6C pools are administered by Philips and Toshiba respectively (Aoki, 2005). One of the key administrative functions is to determine which patents are admitted to the pool. Patent pools are quite restrictive regarding the IP that is admitted. This stems from anti-trust concerns. As explained above, patent pools are efficiency enhancing provided that the patents within the pool are sufficiently complementary in nature. However, pools of patents that are sufficiently substitutable are anti-competitive and allow the member firms to increase profits at the expense of users of the patents. Therefore, membership of a patent pool is usually restricted to those patents that are deemed to be 'essential' to the pool. To satisfy anti-trust authorities, patent pools often employ independent experts to assess essentiality.

\subsection{IP Clearinghouses}

The idea of an IP clearinghouse has recently been discussed by a number of authors to address the economic inefficiencies identified above that arise from a proliferation of IP rights. ${ }^{7}$ A clearinghouse is like a middleman in the market for technology that facilitates exchanges between IP owners and IP users. Its scope is broader than a patent pool and it may have independent objectives. For example, a biotechnology clearinghouse could provide a database of biotechnology patents and allow searching and identification of IP owners. The clearinghouse could also facilitate licensing and handle the collection of royalties and monitoring of uses on behalf of the patent holders. In principle, the clearinghouse could raise revenues from both IP owners and IP users for its services.

The nature of a clearinghouse means that they are generally administered by third-party organizations and not by one or more members. A key question is whether or not the clearinghouse acts on behalf of the member IP owners. Copyright collectives are administered by third-party organizations that operate on behalf of the members of the collective. For example, the American Society of Composers and Performers (ASCAP) is

\footnotetext{
${ }^{6}$ See Verbeure et al (2006) for a summary of these pools and a discussion of issues relating to the formation of patent pools in medical diagnostic testing.

7 See van Zimmeren et al (2006), Van Overwalle et al (2006), Krattinger (2004), OECD (2002), Graff \& Zilberman (2001) and Dequiedt et al (2007).
} 
administered as a voluntary association by a board of directors elected by the members. ${ }^{8}$ In contrast, as we will see, other clearinghouses often operate as independent entities, with their own objectives.

In terms of classification, five different types of clearinghouse are distinguished by van Zimmeren et al (2006), depending on the functions performed. These range from an 'informational' clearinghouse that merely facilitates access to information about IP, through to a 'royalty collection' clearinghouse that provides information, as well as standardized licenses plus royalty monitoring and collection functions. This taxonomy is useful in that it distinguishes the range of different functions that a clearinghouse may perform. In our view, the most important functional distinction is whether or not the clearinghouse provides licenses to IP users directly. We distinguish two functional types of clearinghouse: an informational clearinghouse and a licensing clearinghouse. The former collects and provides access to information about existing IP. The latter provides information and also sells licenses directly, and may perform royalty collection functions.

Of the other dimensions identified in Figure 7, ownership of the clearinghouse is another important point of classification. Ownership will affect the incentives of a clearinghouse when setting the prices (if any) that it charges for its services, and the royalties that it sets, if applicable. The incentives of the clearinghouse will be very different if it is operated as a collective, compared to if it is an independent third-party. Overall, we distinguish four different types of clearinghouse as shown in Figure 8.

Figure 8 Classification of intellectual property clearinghouses.

\begin{tabular}{|c|c|c|c|}
\hline \multirow{2}{*}{ 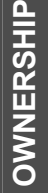 } & $3^{\text {rd }}$ Party & I & II \\
\hline & Collective & III & IV \\
\hline & & $\begin{array}{l}\text { Informational } \\
\text { Clearinghouse }\end{array}$ & $\begin{array}{l}\text { Licensing } \\
\text { Clearinghouse }\end{array}$ \\
\hline & & $\begin{array}{l}\text { Information } \\
\text { Only }\end{array}$ & $\begin{array}{c}\text { Information \& } \\
\text { Licensing }\end{array}$ \\
\hline & & FU & ION \\
\hline
\end{tabular}

Copyright collectives are examples of collective licensing clearinghouses (type IV). These collectives, such as ASCAP, Broadcast Music Incorporated (BMI), and the Japan Society for Rights of Authors, Composers and Publishers (JASRAC), are similar to patent

\footnotetext{
8 See www.ascap.com/about/.
} 
pools in that they provide licenses to packages of IP. Aside from the fact that they apply to copyrights rather than patents, the main feature that distinguishes copyright collectives from patent pools is their scope. A license from a copyright collective typically permits the use of a wide range of copyrighted material, whereas patent pools are limited to a particular technology or standard. The collectives then monitor which works are performed and apportion the total revenues less operating expenses to the copyright owners in accordance with a set formula.

An example of a third-party IP clearinghouse is BirchBob, ${ }^{9}$ which facilitates exchanges between the technology transfer offices of universities and other research institutions with firms that would like to use and license new technologies. In terms of the classification in Figure 8 it is a type I clearinghouse and provides an online searchable database of IP. BirchBob describes itself as an 'innovation agency' that assists innovators with commercializing and licensing their technologies, however it does not sell licenses directly, thus we do not classify it as a licensing clearinghouse.

Other examples include the Public Intellectual Property Resource for Agriculture (PIPRA $)^{10}$ and general patent search services such as the Google patent search. ${ }^{11}$ The Google patent search allows online searching of the full text of the more than seven million patents issued by the USPTO since the 1790s, using specialized text search technology developed by Google. Google does not charge users for searching its database, nor patent holders for being listed, but instead earns revenues indirectly through advertising on its website. It is another example of a third-party informational clearinghouse (type I). PIPRA is a non-profit organization that aims to encourage agricultural development by facilitating access to relevant IP. It currently does this mainly by providing a database of relevant patents. Thus it is another type I clearinghouse, although it is non-profit. PIPRA also states that it has aims to create packages of complementary agricultural IP and license these to users. ${ }^{12}$ If it does so, it would become a type II clearinghouse.

In contrast with patent pools, clearinghouses (including copyright collectives) are quite open in terms of the IP that they admit. For example, it is possible to join BMI online very easily, at no cost. ${ }^{13}$ BirchBob and Yet2.com also permit listings of technologies by anyone who pays a set fee. This may be explained because the value of a clearinghouse increases as more IP is admitted, everything else equal (see section 4.2 below). The only

\footnotetext{
9 See www.birchbob.com.

${ }^{10}$ See van Zimmeren et al (2006) for a summary.

11 www.google.com/patents/

12 See www.pipra.org/main/activities.htm\#3.

${ }^{13}$ See www.bmi.com/join/.
} 
restriction typically encountered is with specialized clearinghouses that concentrate on a particular subject matter, such as PIPRA.

As explained above, copyright collectives fall into type IV in our classification of clearinghouses. We are not aware of any type II or III clearinghouses that currently exist. In principle, third-party licensing clearinghouses (type II) could operate in a similar fashion to copyright collectives. We are also not aware of any type IV clearinghouse that provides access to patents, and the complexity of writing standardized licenses for patented innovations is suggested by van Zimmeren et al (2006) as a possible explanation for this.

Table 2 summarizes the type I clearinghouses that we have been able to identify. We have separated them into two groups. The first, IP database search engines, provide either free or subscription services that permit searching of one or more databases of IP. The second group, IP exchange platforms, may provide database search services, but also permit IP owners with licensable technologies (consisting of one or more patented innovations) to advertise and permit IP users to search these advertisements. Thus the second group allows IP owners to take a more active role in their use of the clearinghouse. Some of these exchange platforms, such as BirchBob and Yet2.com also assist with licensing negotiations by providing consulting services. 
Table 2 Third-party informational clearinghouses (type I) that we have identified.

\begin{tabular}{|c|c|c|c|c|c|c|}
\hline \multirow{2}{*}{ Name } & \multirow{2}{*}{ Website } & \multirow{2}{*}{ Field } & \multirow{2}{*}{ Included IP } & \multirow{2}{*}{$\begin{array}{l}\text { Information } \\
\text { Sources }\end{array}$} & \multicolumn{2}{|l|}{ Pricing } \\
\hline & & & & & Search & Advertising \\
\hline \multicolumn{7}{|c|}{ IP Database Search Engines } \\
\hline $\begin{array}{l}\text { CAMBIA } \\
\text { Patent Lens }\end{array}$ & patentlens.net & General & Patents & $\begin{array}{l}\text { Patent } \\
\text { databases }\end{array}$ & Free & $\mathrm{N} / \mathrm{A}$ \\
\hline $\begin{array}{l}\text { Delphion } \\
\text { Research }\end{array}$ & delphion.com & General & Patents & $\begin{array}{l}\text { Patent } \\
\text { databases }\end{array}$ & Subscription & $\mathrm{N} / \mathrm{A}$ \\
\hline $\begin{array}{l}\text { Google } \\
\text { Patents }\end{array}$ & $\begin{array}{l}\text { google.com/ } \\
\text { patents }\end{array}$ & General & Patents & $\begin{array}{l}\text { USPTO } \\
\text { filings }\end{array}$ & Free & $\mathrm{N} / \mathrm{A}$ \\
\hline PatentCafe & patentcafe.com & General & Patents & $\begin{array}{l}\text { Patent } \\
\text { databases }\end{array}$ & Subscription & $\mathrm{N} / \mathrm{A}$ \\
\hline PIPRA* & pipra.org & Agriculture & Patents & $\begin{array}{l}\text { Patent } \\
\text { databases }\end{array}$ & Free & $\mathrm{N} / \mathrm{A}$ \\
\hline $\begin{array}{l}\text { Thomson } \\
\text { Dialog }\end{array}$ & dialog.com & General & $\begin{array}{l}\text { Patents, } \\
\text { trademarks, } \\
\text { copyrights }\end{array}$ & IP databases & Subscription & $\mathrm{N} / \mathrm{A}$ \\
\hline $\begin{array}{l}\text { Thomson } \\
\text { MicroPatent }\end{array}$ & micropat.com & General & Patents & $\begin{array}{l}\text { Patent } \\
\text { databases }\end{array}$ & Subscription & $\mathrm{N} / \mathrm{A}$ \\
\hline $\begin{array}{l}\text { Thomson } \\
\text { Pharma }\end{array}$ & $\begin{array}{l}\text { thomson } \\
\text { pharma.com }\end{array}$ & Pharma & Patents & $\begin{array}{l}\text { Patent } \\
\text { databases }\end{array}$ & Subscription & $\mathrm{N} / \mathrm{A}$ \\
\hline $\begin{array}{l}\text { WIPO Digital } \\
\text { Library* }\end{array}$ & wipo.int/ipdl/en/ & General & $\begin{array}{l}\text { Patents, } \\
\text { trademarks, } \\
\text { designs }\end{array}$ & $\begin{array}{l}\text { WIPO } \\
\text { database }\end{array}$ & Free & $\mathrm{N} / \mathrm{A}$ \\
\hline \multicolumn{7}{|c|}{ IP Exchange Platforms } \\
\hline BirchBob & birchbob.com & General & $\begin{array}{l}\text { Licensable } \\
\text { technologies }\end{array}$ & Submissions & Free & Subscription \\
\hline $\begin{array}{l}\text { Idea Trade } \\
\text { Network }\end{array}$ & $\begin{array}{l}\text { newideatrade. } \\
\text { com }\end{array}$ & General & $\begin{array}{l}\text { Licensable } \\
\text { technologies }\end{array}$ & Submissions & Free & Per-listing fee \\
\hline $\begin{array}{l}\text { MVS } \\
\text { Solutions }\end{array}$ & mvssolutions.net & General & $\begin{array}{l}\text { Licensable } \\
\text { technologies }\end{array}$ & Submissions & Free & Commission \\
\hline $\begin{array}{l}\text { Pharma- } \\
\text { Transfer }\end{array}$ & $\begin{array}{l}\text { pharma- } \\
\text { transfer.com }\end{array}$ & $\begin{array}{l}\text { Pharma \& } \\
\text { biotech }\end{array}$ & $\begin{array}{l}\text { Licensable } \\
\text { technologies }\end{array}$ & Submissions & Subscription & Subscription \\
\hline TechEx & techex.com & $\begin{array}{l}\text { Biomedical } \\
\text { science }\end{array}$ & $\begin{array}{l}\text { Licensable } \\
\text { technologies }\end{array}$ & $\begin{array}{l}\text { Patent } \\
\text { databases, } \\
\text { submissions }\end{array}$ & Subscription & Free \\
\hline Yet2 & yet2.com & General & $\begin{array}{l}\text { Licensable } \\
\text { technologies }\end{array}$ & $\begin{array}{l}\text { Patent } \\
\text { databases, } \\
\text { Submissions }\end{array}$ & $\begin{array}{l}\text { Free (basic), } \\
\text { or } \\
\text { subscription }\end{array}$ & $\begin{array}{l}\text { Subscription, } \\
\text { commission }\end{array}$ \\
\hline
\end{tabular}

* Operates on a non-profit basis.

\section{Comparing the Economic Features of IP Access Systems}

In this section we discuss and compare the essential economic features of different IP access systems. We are interested in the effect on economic outcomes illustrated in Figure 5 in the context of the framework from Figure 4. In general this depends on (i) the incentives of the system, which in turn depends on whether the system is a collective or independent third party, and (ii) the scope that the system has for realizing efficiency gains in terms of reducing search and transaction costs and solving the tragedy of the 
anticommons. We also discuss the role that 'network' effects play in the system's operation, and factors determining a system's stability.

\subsection{The Economic Value of IP Access Systems}

As illustrated in Figure 6, all systems provide a 'platform' that facilitates licensing arrangements, and reduce search and transaction costs in the licensing process. For example, a user of a technology covered by a patent pool need not worry about the specific IP rights contained within the pool. This reduces the licensee's costs because it only needs to identify and negotiate with the pool, rather than all members individually. Similarly, an access agreement with a licensing clearinghouse such as a copyright collective immediately identifies exactly which IP can be used under the agreement. Informational clearinghouses may also give users the ability to search for existing IP more efficiently than they could through independent search, if the scale of the clearinghouse allows it to deploy a more effective search technology. For example, Google's patent search technology is arguably more effective than what most small-scale licensees could implement independently. This is because aggregation of the search function into a single entity means that more sophisticated and expensive search technologies can be employed as the costs can be recovered from a broader base of users.

In terms of transaction costs, patent pools and licensing clearinghouses can create value by exploiting economies of scale in licensing and negotiation. If a product or downstream innovation requires licenses to $N$ existing innovations and there are $M$ potential licensees, then $N \times M$ licensing arrangements must be made in the absence of an IP access system. Even if each licensor offers standardized licenses, there are still a potentially large number of transactions that must occur when the innovation is complex ( $N$ is large) and/or there are many licensees ( $M$ is large). In comparison, suppose that with an IP access system, each licensor and each licensee makes a single agreement with the system. In this case there are $N+M$ agreements that must be made. The access system reduces the number of agreements that need to be made if $N+M<$ $N \times M$, or if $M>N /(N-1)$, that is, if the number of licensees is sufficiently large relative to the number of licensors. There may be additional savings if the system offers standardized licenses, compared to if each licensor has to write its own license agreement.

In addition, the marginal cost of adding an extra licensee to the system does not change with the number of licensors that use the system (the marginal cost of increasing $M$ does not depend on $N$ ). In contrast, with bilateral negotiations, the marginal cost of increasing $M$ is higher the greater is $N$. These reduced costs are likely to mean that there will be greater entry of licensees under an IP access system, which will mean increased 
competition in the market for the final good or service that is being produced, further enhancing economic efficiency.

In the case of complementary IP, an IP access system may also create value by internalizing the externalities that lead to the tragedy of the anticommons, if license fees are set centrally. In effect, joint setting of license fees aggregates the multiple overlapping IP rights into a single right, which eliminates the source of the tragedy of the anti-commons. However, as was shown, this does not hold true when the IP rights are substitutes. Thus it is more difficult to say in general whether licensing clearinghouses including copyright collectives that set license fees centrally would improve economic efficiency by mitigating the tragedy of the anticommons. It would depend on the particular mix of IP that is included in the system, but in general if a broad range of IP is included then the individual rights are more likely to be substitutes rather than complements.

In summary, all IP access systems improve economic efficiency by reducing search and transaction costs. This reduces the cost of downstream innovation and developing new products based on combinations of existing IP. Patent pools can further improve efficiency if the member patents are sufficiently complementary. However, by their nature of incorporating a broad range of IP, it is less likely that the IP available through a licensing clearinghouse such as a copyright collective will be sufficiently complementary that joint license fee setting will be efficiency enhancing. Nevertheless, such clearinghouses can still be desirable, if there is a net gain in economic efficiency due to reduced costs.

\subsection{Incentives of the System}

The extent to which the potential efficiency gains of an IP access system are realized depend in part on its own incentives. The incentives of the system determine the prices that it charges to its customers - downstream users and/or IP owners - for the services that it provides. The crucial question is whether the system operates on behalf of a group of licensors, or whether it is a truly independent third-party. In the former case, the system will seek to achieve the goal of the licensors, such as maximization of their joint revenues. If it is a third-party then its objective may be to maximize its own profit, or some other objective if it is a non-profit entity.

Patent pools and type III and IV clearinghouses such as copyright collectives operate in the interests of the members who have contributed IP. Typically, any revenues earned by the pool or collective are redistributed to members according to some formula, minus the cost of administrative expenses. For example, ASCAP states that its objective is to "maximize payments to members", and claims that it redistributes $88 \%$ of its revenues 
to members. ${ }^{14}$ Similarly, the royalties received from patent pool licenses such as those sold by MPEG-LA and the DVD pools are redistributed to the members of the pool. In contrast, third-party clearinghouses (type I and II) operate according to their own objectives. The profit-making informational clearinghouses (type I) in Table 2 revenue directly or indirectly from either of these two groups. For example, Yet2.com raises revenues by charging subscription fees and/or commissions to both IP owners and IP users for its services.

The other factor affecting the system's incentives is the 'demand' that it faces. Since the value of an IP access system comes from the licensing platform that it provides to IP owners and downstream users, the demand that the system faces is likely to be characterized by 'network' effects. The demand for a good or service exhibits network effects when it becomes more valuable to its consumers the greater the number of people who consume it. This has important implications for the behavior of firms and market outcomes. Consumer expectations become important, and different levels of demand can be supported at a given price depending on whether expectations about the uptake of the good or service are optimistic or pessimistic (see the discussion on stability below). Markets with network effects also often 'tip' towards one good or service and tend to be characterized by a single dominant firm at any one point in time, and inferior products may be able to survive longer than they otherwise would in the face of superior competition.

In the general case of an IP access platform as illustrated in Figure 6, these network effects operate across the platform. That is, there are two distinct groups that the platform serves: IP owners and IP users. Each group would like to join a platform that has more of the other type using the same platform. Specifically, IP owners would like to join a platform that has more IP users, everything else equal, because this will increase the royalties that they expect to receive. Similarly, IP users would like to join a platform that has more IP owners, everything else equal, because it gives access to a greater range of IP that can be exploited. That is, a general IP access system operates what has become known as a 'two-sided platform' (Rochet \& Tirole 2003, 2006, Caillaud \& Jullien 2003).

However, this observation that does not apply to the specific cases of patent pools and collective clearinghouses (types III and IV) such as copyright collectives, due to the way that these systems operate. First, a patent pool serves the interests of its members. The pool itself does not seek to earn any revenues from patent holders, and therefore only targets one side of the market - the IP users. Admission to the pool is also not based on willingness to pay a price, but rather an assessment of essentiality. Conceptually, pools

${ }^{14}$ See www.ascap.com/about/payment/paymentintro.html. 
do not exist independent of patent holders and do not seek to attract patent holders to raise revenue. Rather, pools are formed by the patent holders themselves.

Collective clearinghouses such as copyright collectives are similar to patent pools in that they exist to maximize the joint royalty revenues of the members, and do not raise revenues from members. As with a patent pool, a collective clearinghouse is not a twosided platform because it operates on behalf of one side of the market, rather than seeking to raise revenues from both sides. However, collective clearinghouses do exhibit network effects. As discussed above, the collective promotes more efficient access by the users to the IP held in the collective. A collective with more works will therefore be more valuable to users than a smaller collective, everything else equal. Similarly, joining a collective will be more attractive to an IP owner if more IP users get licenses from the collective, as the amount of royalties that the IP owner expects to receive will increase.

Unlike patent pools and collective clearinghouses, third-party clearinghouses are examples of two-sided platforms. Such a clearinghouse can raise revenues from both IP owners and IP users, and seeks to maximize its own profits, rather than the joint royalty revenues of the IP owners. As has been discussed in the literature, operating a two-sided platform is more complex than a firm that produces a single product or that produces multiple but unrelated products. A two-sided platform must consider the demands on both sides of the market simultaneously when making its pricing decisions. This is because an increase in the price charged to one group, for example, will reduce the number of members of the platform from that group, which will then affect the willingness to pay of the other group, via the cross-platform network effect. Two-sided platforms also face the same problem that all network businesses face in that since the value of the platform partially or completely comes from network effects, it may be difficult to get established, particularly if IP right owners and users have pessimistic expectations about the likely success of the platform.

\subsection{Stability}

A final important economic consideration is the stability of the different systems. Instead of participating in an IP access system, any IP owner can choose to be an 'outsider' and license his or her IP to users directly. The incentives for IP owners to join or remain in a system are therefore crucial in determining the ability of the system to get off the ground in the first place, and its ongoing stability once it is established. Stability and formation of collectives are related, but not exactly the same problem.

For clearinghouses, including copyright collectives, there is likely to be a tendency towards stability, due to the network effects among IP owners (Aoki, 2006). Given that other IP owners are members of the clearinghouse, any individual IP owner's incentive 
is to belong, rather than becoming an outsider. Such stability of clearinghouses is partly evidenced by the longevity of copyright collectives such as ASCAP (established in 1914) and BMI (established in 1939). However as mentioned above there is a possibility of multiple equilibria: there can be an equilibrium with many members and another one with very small membership at the same membership price. If there are few members, there are few people that find it worthwhile to join which keeps membership small. A small membership equilibrium can be stable and there is no endogenous way to move between equilibria. Guaranteeing a large membership equilibrium requires some kind of intervention by the clearinghouse (Aoki, 2006).

The issue of stability and formation is more critical for patent pools. Recall that patent pools solve the tragedy of the anticommons problem by internalizing the externalities that exist among pool members. However, this same mechanism means that any individual pool member has an incentive to become an outsider and 'free ride' on the pool, at least when royalties are distributed to members in proportion to the number of patents that they contribute to the pool (Aoki, 2005, 2006). In other words, the same reason that makes patent pools valuable also makes them unstable. Starting from the royalty level that is optimal for the pool (i.e. the level that maximizes joint royalties), any individual member would prefer to leave the pool and set a higher royalty for its patent(s). Since an outsider would not choose the pool royalty level, it implies that an outsider could make more profits, given that all others remain in the pool. Therefore, each member has a unilateral incentive to leave the pool once it is formed, which undermines the pool's stability. This same principle also gives a patent holder an incentive to hold out and refuse to join the pool after the pool has become a certain size. Furthermore, a rational patent holder will correctly expect a pool of some size to form and refuse to join from the very beginning.

Instability of patent pools can also arise from heterogeneity among members. If some members are research-only firms while others are integrated research and manufacturing firms, then the marginal effect of a change in the pool royalty on these two types of firms is different. This is because the royalty affects only revenues for a research firm, but both revenues and costs for an integrated firm. This means that research-only firms generally prefer to remain outsiders rather than joining a pool with integrated firms, unless the research firms receive disproportionately higher royalty payments (Aoki \& Nagaoka, 2004, Aoki, 2006). This also implies that research firms need disproportionately more inducement to join a pool at the formation stage. Binding agreements and 'punishments' for exiting the pool may also be necessary.

Additional problems may arise in the process of pool formation, due to the fact that smaller pools consisting of only some of the essential patents may have an incentive to 
block the formation of a larger pool of all essential patents. In particular, using cooperative game theory Aoki and Nagaoka (2005) show that if the number of firms with essential patents is large enough, a smaller pool consisting of only some essential patents makes its members better off than the absence of a pool, and that the members of the smaller pool would be made worse off if additional members were admitted. This may explain why patent pools are less common than they otherwise would be, or that some pools do not include all essential IP and thus do not achieve the maximum benefits of pool formation.

However we observe that some pools have indeed formed. Schiff and Aoki (2007) examine pool formation by competing consortium standards. They show that if there is another standard that competes, in some cases this can increase incentives for pool formation. The pools that have formed do not always have a competing standard but it could be that threat or potential emergence of a competing standard had been enough for pool formation. However there are also some cases where patent owners find it more profitable not to form a pool when standards compete, because not pooling is a way for a standard to commit to setting a high total royalty, which may be desirable when in competition with another standard.

\section{Conclusion}

In this paper we have reviewed patent pools and IP clearinghouses (including copyright collectives) as systems that promote access to IP. These promote downstream uses of IP such as cumulative innovation and the development of products based on multiple innovations by reducing search and transaction costs, and help to solve the tragedy of the anticommons that occurs with complementary IP. Each system has different features and each is more suitable in certain situations. Patent pools are ideal in situations where complementary patents must be combined to produce a new product or innovation and the essential patents are easy to identify. This reduces transaction and search costs for licensors and licensees, and mitigates the tragedy of the anticommons. The disadvantages of patent pools are that they are generally limited in scope by antitrust concerns, and they can be difficult to set up and maintain stability especially when there is heterogeneity among the pool members.

Collective clearinghouses such as copyright collectives have worked well to reduce the costs of licensing and monitoring the use of copyrighted works. Copyright collectives contain a much broader range of IP than patent pools. Due to network effects, we expect that copyright collectives are inherently more stable than patent pools. However, copyright collectives have come under some scrutiny as collectives set license fees centrally, and many of the works in a collection are likely to be substitutes. 
Other third-party clearinghouses dealing mainly in patents are a relatively new phenomenon, due to the reduced costs of collecting and disseminating information over the Internet. The existing third-party clearinghouses do not sell licenses directly, but provide a 'matching service' of varying degrees of sophistication between IP owners and users. This economizes on search and transaction costs, but without centralized licensing cannot solve the tragedy of the anticommons problem. Third-party clearinghouses usually operate as independent profit-maximizing firms, and so have an incentive to maximize the economies of scale in licensing and negotiation that they can generate. Third-party clearinghouses also exhibit network effects, which flow across the platform that they provide, and make them an example of a two-sided platform, with relatively complex pricing problems.

In terms of future economic research, our overview of these different systems raises a number of interesting questions. First, a better understanding of the economics of thirdparty IP clearinghouses is needed. It would be useful to apply the lessons of the twosided markets literature to this type of platform. One possible complication is that the two sides of the market are not always clearly separated in the case of IP, as licensors are often also licensees. It would be also interesting to compare directly the economic incentives of a third-party clearinghouse versus a collective clearinghouse. Of further interest would be a more detailed comparison of the economic aspects of the different systems in terms of their effects on reducing costs of cumulative innovation and product development, and in solving the tragedy of the anticommons. Ultimately, a consistent framework within which the different systems can be compared is needed. Using such a framework, the effects of the different types of system on innovation and welfare could be assessed, which may lead to more specific policy recommendations.

\section{References}

Athreye, S. \& J. Cantwell (2007). Creating competition? Globalization and the emergence of new technology producers. Research Policy, 36: 209-226.

Aoki, R. (2005). Intellectual property and consortium standard patent pools. Journal of Intellectual Property Rights, 10: 206-213.

Aoki, R. (2006). Clearing houses and patent pools -- Access to genetic patents. Department of Economics Working Paper \#264, University of Auckland.

Aoki, R. \& S. Nagaoka (2004). The consortium standard and patent pools, The Economic Review, 55: 346-356.

Aoki, R. \& S. Nagaoka (2005). Coalition formation for a consortium standard through a standard body and a patent pool: Theory and evidence from MPEG2, DVD and 3G. 
Institute of Innovation Research, Hitotsubashi University, IIR Working Paper WP\#0501.

Arora, A. \& A. Fosfuri (2003). Licensing the market for technology. Journal of Economic Behavior and Organization, 52: 277-295.

Arora, A., A. Fosfuri \& A. Gambardella (2001). Markets for Technology. MIT Press: Cambridge.

Buchanan, J. \& Y. Yoon (2000). Symmetric tragedies: Commons and anticommons. Journal of Law and Economics, 43: 1-13.

Caillaud, B. \& B. Jullien (2003). Chicken \& egg: Competition among intermediation service providers. RAND Journal of Economics, 34: 309-328.

Dequiedt, V., Y. Meniere \& M. Trommetter (2007). Collective management of intellectual property rights. Laboratoire d'Economie Appliquée de Grenoble, Working Paper 2007-04.

Gallini, N. \& B. Wright (1990). Technology transfer under asymmetric information. RAND Journal of Economics, 21: 147-160.

Gambardella, A., P. Giuri \& A. Luzzi (2006). The market for patents in Europe. Research Policy, 36: 1163-1183.

Graff, G. \& D. Zilberman (2001). Towards an intellectual property clearinghouse for agbiotechnology: An issues paper. IP Strategy Today, 3: 1-17.

Giuri, P., M. Mariani, S. Brusoni, G. Crespi, D. Francoz, A. Gambardella, W. GarciaFontes, A. Geuna, R. Gonzales, D. Harhoff, K. Hoisl, C. Le Bas, A. Luzzi, L. Magazzini, L. Nesta, O. Nomaler, N. Palomeras, P. Patel, M. Romanelli, B. Verspagen (2007). Inventors and invention processes in Europe: Results from the PatVal-EU survey. Research Policy, 36: 1107-1127.

Heller, M. A. \& R. S. Eisenberg (1998). Can patents deter innovation? The anticommons in biomedical research. Science, 280: 698-701.

Hope, J. (2004). Open Source Biotechnology. PhD thesis, Australian National University. Downloaded from sss.anu.edu.au/ janeth/OpenSourceBiotechnology27July2005.pdf.

Kamien, M \& Y. Tauman (1986). Fees versus royalties and the private value of a patent. Quarterly Journal of Economics, 101: 471-491.

Katz, M. \& C. Shapiro (1985). On the licensing of innovations. RAND Journal of Economics, 16: 504-520.

Krattinger, A. F. (2004). Financing the bioindustry and facilitating technology transfer. IP Strategy Today, 8: 1-45.

Lerner, J. \& J. Tirole (2004). Efficient patent pools. American Economic Review, 94: 691-711.

OECD (2002). Genetic Inventions, Intellectual Property Rights and Licensing Practices: Evidence and Policies. Downloaded from www.oecd.org/dataoecd/42/21/2491084.pdf.

OECD (2006). Compendium of Patent Statistics 2006. Downloaded from www.oecd.org/sti/ipr-statistics. 
Razgaitis, R. (2005). U.S./Canadian licensing in 2004: Survey results. Les Nouvelles, 35: 145-155.

Razgaitis, R. (2004). U.S./Canadian licensing in 2003: Survey results. Les Nouvelles, 34: 139-151.

Rochet, J.-C. \& J. Tirole (2003). Platform competition in two-sided markets. Journal of the European Economic Association, 1: 990-1029.

Rochet, J.-C. \& J. Tirole (2006). Two-sided markets: A progress report. RAND Journal of Economics, 37: 645-667.

Scherer, F. M. (2002). The economics of human gene patents. Academic Medicine, 77: 13481367.

Schiff, A. \& R. Aoki (2007). Differentiated standards and patent pools. Mimeo, available from ssrn.com/abstract $=1004427$.

Shapiro, C. (2001). Navigating the patent thicket: Cross licenses, patent pools and standard setting. In Jaffe, E., Lerner, J. \& Stern, S., eds, Innovation Policy and the Economy, Volume I. MIT Press: Cambridge.

USPTO (2005). US Patent Statistics Report 2005. Downloaded from www.uspto.gov/web/offices/ac/ido/oeip/taf/reports.htm.

Van Overwalle, G., E. van Zimmeren, B. Verbeure, G. Matthijs (2006). Models for facilitating access to patents on genetic innovations. Nature Reviews Genetics, 7: 143154.

Verbeure, B., E. van Zimmeren, G. Matthijs \& G. Van Overwalle (2006). Patent pools and diagnostic testing. TRENDS in Biotechnology, 24: 115-120.

van Zimmeren, E., B. Verbeure, G. Matthijs \& G. Van Overwalle (2006). A clearing house for diagnostic testing: The solution to ensure access to and use of patented genetic innovations? Bulletin of the World Health Organization, 84: 352-359. 